Portland State University

PDXScholar

$10-2018$

\title{
Ecosystem Services and U.S. Stormwater Planning: An Approach for Improving Urban Stormwater Decisions
}

Todd K. BenDor

University of North Carolina at Chapel Hill

Vivek Shandas

Portland State University, vshandas@pdx.edu

Brian Miles

University of North Carolina at Chapel Hill

Kenneth Belt

Northern Research Station, Baltimore Field Station, USDA Forest Service

Lydia Olander

Duke University

Follow this and additional works at: https://pdxscholar.library.pdx.edu/usp_fac

Part of the Natural Resources Management and Policy Commons Let us know how access to this document benefits you.

\section{Citation Details}

BenDor, T. K., Shandas, V., Miles, B., Belt, K., \& Olander, L. (2018). Ecosystem services and US stormwater planning: An approach for improving urban stormwater decisions. Environmental science \& policy, 88, 92-103.

This Article is brought to you for free and open access. It has been accepted for inclusion in Urban Studies and Planning Faculty Publications and Presentations by an authorized administrator of PDXScholar. Please contact us if we can make this document more accessible: pdxscholar@pdx.edu. 


\title{
Ecosystem services and U.S. stormwater planning: An approach for improving urban stormwater decisions
}

\author{
Todd K. BenDor ${ }^{\mathrm{a}, *}$, Vivek Shandas ${ }^{\mathrm{b}}$, Brian Miles ${ }^{\mathrm{c}}$, Kenneth Belt ${ }^{\mathrm{d}}$, Lydia Olander ${ }^{\mathrm{e}}$ \\ a Department of City and Regional Planning and UNC Institute for the Environment, University of North Carolina at Chapel Hill, New East Building, Campus Box \#3140, \\ Chapel Hill, NC 27599-3140, United States \\ b Department of Urban Studies and Planning, Portland State University, Portland, OR 97207, United States \\ ${ }^{\mathrm{c}}$ Institute for the Environment, University of North Carolina at Chapel Hill, Chapel Hill, NC 27599, United States \\ ${ }^{\mathrm{d}}$ Northern Research Station, Baltimore Field Station, USDA Forest Service, Baltimore, MD 21228, United States \\ ${ }^{\mathrm{e}}$ Nicholas Institute, Duke University, Durham, NC 27708, United States
}

\section{A R T I C L E I N F O}

\section{Keywords:}

Environmental planning

Ecosystem services

Stormwater planning

Green infrastructure

Stormwater infrastructure

Low impact development

\begin{abstract}
A B S T R A C T
Green stormwater infrastructure (GI) is gaining traction as a viable complement to traditional "gray" infrastructure in cities across the United States. As cities struggle with decisions to replace deteriorating stormwater infrastructure in the face of looming issues such as population growth and climate change, GI may offer a costeffective, efficient, and sustainable approach. However, decision makers confront challenges when integrating GI within city plans, including uncertainties around GI capacity and maintenance, resistance to collaboration across city governance, increasingly inflexible financing, accounting practices that do not incorporate the multiple values of GI, and difficulties in incorporating ecological infrastructure into stormwater management. This paper presents an ecosystem services framework for assessing the context-specific needs of decision makers, while considering the strengths and limitations of GI use in urban stormwater management. We describe multiple dimensions of the planning system, identify points of intervention, and illustrate two applications of our framework - Durham, North Carolina and Portland, Oregon (USA). In these case studies, we apply our ecosystem services framework to explicitly consider tradeoffs to assist planning professionals who are considering implementation of GI. We conclude by offering a research agenda that explores opportunities for further evaluations of GI design, implementation, and maintenance in cities.
\end{abstract}

\section{Introduction}

Many cities are confronting severe public infrastructure challenges, including rapidly deteriorating road networks, energy systems, and water delivery and stormwater management systems (ASCE, 2013). In the United States, studies suggest that in the coming decades American cities will need to invest between $\$ 10$ and $\$ 50$ trillion dollars to replace existing infrastructure (Dobbs et al., 2013). Failures of these systems pose risks to citizens, businesses, and planning efforts, and endanger public health, mobility, landscape resilience, and environmental quality (Zimmerman, 2009). Over the last decade, the emergence of two important concepts offers opportunities for addressing pressing infrastructure needs, as they pertain to stormwater: green stormwater infrastructure and ecosystem services.

First, green stormwater infrastructure (GI) generally refers to the use of vegetation and soil ecosystems for the management of stormwater, generally closer to the source of runoff (USEPA, 2013b). Fletcher et al. (2014) discuss the enormous range of terminology (e.g. BMP, SUDS, LID) and theoretical frameworks applied to GI, which are derived from use in different fields, countries, time periods, and urban-rural contexts. In the United States, the most common term referenced in this area is "Best Management Practice" (BMP), which includes a range of agricultural and urban stormwater practices. In the context of this paper, we consider GI as the use of "green" materials such as turfed swales or vegetated infiltration beds, native plants, and rock features suggests a more natural, sustainable approach to slowing, retaining, and treating stormwater runoff. Treatment and conveyance facilities like bio-retention cells, rain gardens, step pools, and bio-swales can be built as artistic features, and offer stark contrast to concrete lined channels, turfed expanses and metal or concrete outlet structures, whose larger basin designs are less able to mimic pre-development hydrological processes and regimes (Burns et al., 2012; Echols, 2007).

Second, the concept of "ecosystem services" (ES) has emerged as an important organizing principle for addressing current challenges to

\footnotetext{
* Corresponding author.

E-mail addresses: bendor@unc.edu (T.K. BenDor), vshandas@pdx.edu (V. Shandas), brian_miles@unc.edu (B. Miles), kbelt@fs.fed.us (K. Belt), lydia.olander@duke.edu (L. Olander).
} 
sustaining the environmental functions upon which people and their economies depend. ES have been defined as the benefits to humans that are a result of ecological systems (Millennium Ecosystem Assessment, 2005). Ecological systems deliver a variety of ES to human society, including provisioning (e.g. food, water), supporting (e.g. nutrient cycling), regulating (e.g. flood regulation), and cultural services (e.g. aesthetics).

The application of GI and ES to urban infrastructure management, however, requires more evidenced-based evaluations, which are currently underway across the United States (Bloorchian et al., 2014; Flynn and Traver, 2013; Keeley et al., 2013; Nylen and Kiparsky, 2015). US GI planning has not yet adopted the concept of ES as a way of evaluating tradeoffs between different infrastructure options. The integration of ES in planning has almost exclusively occurred in either 1) western-European focused spatial-planning concepts (Albert et al., 2014a; Bryan, 2013; Sumarga and Hein, 2014); 2) conservation planning (typically focused on biodiversity conservation; Chan et al., 2011, 2006; Luck et al., 2012; Palacios-Agundez et al., 2014); or 3) changing agricultural settings (Bryan, 2013; Sumarga and Hein, 2014). However, with several key exceptions (e.g. Tzoulas et al., 2007), studies have largely avoided the larger context within which American urban planning and decision making occurs.

In this article, we offer a framework - adapted from BenDor et al. (2017) - for practicing planners and researchers to assess potential tradeoffs along the continuum of gray and green stormwater infrastructure, and ultimately to determine what options are best suited to different contexts. As we will show, in some cases GI solutions can represent win-win outcomes for improving ES outcomes that increase net societal value, ecosystem resilience, and economic efficiency (e.g. Everard and McInnes's (2013) "systemic solutions" concept).

Our primary thesis is that assessments of ES, which frequently integrate a broader set of social and biophysical factors than traditional evaluations allow, can identify new opportunities and constraints for reducing storm flow volume and the delivery of contaminants to downstream ecosystems. Furthermore, areas adopting an ES framework may be able to establish a broader consideration of benefits of GI than previously attributed to infrastructure management, which can be used to evaluate the value of integrating GI into existing systems. By speaking to related stormwater management methods, such as urban forests, green roofs, urban river corridor restoration, within the same conceptual framework and vision, planners and managers using an ES framework can more clearly optimize benefits (Everard and Moggridge, 2012) and pool siloed budgets to lower management costs.

By "ES framework" or "ES approach," we refer to the use of ES concepts, measurements, theories, and models as a major factor in analyzing planning decisions, engaging in planning processes, and making recommendations for future action (see examples in Olander and Maltby, 2014). As such, we will argue that ES should not be interpreted as simply another new type of accounting system ("old wine in new bottles"); an ES approach represents much more than another in a long line of improvements to Nathaniel Lichfield's (1960) "planning checklist," further expanding how planners perform cost-benefit analysis. Instead, an ES framework could represent a genuine change in thinking around stormwater infrastructure decisions by taking a systems-oriented approach to explicitly linking ecosystem features to the spectrum of services and disservices that they provide. Each of these features have associated constituencies that are affected positively or negatively by interventions.

We begin by contextualizing the challenges facing infrastructure planning by providing an overview of urban stormwater issues as they pertain to planning practice. We then adapt an ecosystem service-based conceptual framework - recently developed by BenDor et al. (2017) for evaluating the potential benefits and drawbacks of incorporating GI into urban planning. This framework allows us to evaluate and critique the nexus of stormwater planning and ES as it has played out in two emblematic case studies of GI planning and participatory processes,
Durham, North Carolina and Portland, Oregon (USA). We address two questions:

(1) How do planners operationalize an ES-framework for weighing green and gray stormwater infrastructure as they make decisions that incorporate communities values and needs?

(2) How can cities evaluate ecosystem service tradeoffs between green and gray stormwater infrastructure?

Finally, we conclude by outlining a proposed research program, calling for investigation into specific dimensions of urban stormwater management as it relates to ES.

\section{Background}

\subsection{Increasing complexity of urban stormwater management}

In developed areas, impervious surfaces like rooftops and driveways short-circuit infiltration processes and prevent precipitation from being naturally absorbed by vegetation and soils (Shuster et al., 2005). Instead, runoff rapidly flows into storm drains, drainage ditches, and finally to stream networks, resulting in a multitude of impacts known as the "urban stream syndrome" (National Research Council, 2009; Paul and Meyer, 2001; Walsh et al., 2005). These impacts include: 1) earlier and increased volumes and rates of run-off, 2) channel erosion (Hammer, 1972), habitat destruction, and infrastructure damage, 3) downstream flooding, 4) sewerage overflows, 5) high nutrients, contaminants, and suspended sediment loads, 6) elevated and rapidly changing temperatures (Nelson and Palmer, 2007), and 7) sewer and storm drain damage. There are also longer term impacts on associated ecosystems, such as continued channel erosion and head-cutting of urban streams (Koryak et al., 2001, Leopold et al., 2005), disconnection of riparian zones and floodplains from streams and groundwater flow paths (Allan, 2004, Everard and Moggridge, 2012; Groffman et al., 2003, Naiman and Décamps, 1997), and excessive nitrogen delivery to coastal waters (Bernhardt et al., 2008). For an overview of the history and on-going issues within stormwater management, please see Supplementary Information 1.

Improvements to stormwater management can be constrained by a variety of factors, including a ruinous combination of a lack of a shared recognition of the multiple-geographic scales associated with stormwater runoff impacts, and an absence of incentives for GI designs that innovate outside of current, regulated engineering-design institutions. For example, federal stormwater rules (33 USC § 1342) often specify very tightly defined spatial and temporal effects that can be considered when monitoring or regulating stormwater; wastewater treatment plant nitrogen measurements are made at defined intervals over a narrow section of waterway. Federal rules, as a result, can eliminate the ability to holistically consider non-point source discharges or the downstream dynamics of small discharges (including aggregation or transformation).

\subsection{Ecosystem services and urban planning}

Over two decades ago, Slocombe (1993) outlined the difficulties in merging broader perspectives of environmental dynamics from ecology into planning practice. More recently, a survey by Mascarenhas et al. (2014) of urban planners found continuing low levels of knowledge regarding major concepts in ES and its potential role in guiding planning decisions. Disparities in philosophy, history, and institutional integration have long separated the two fields. In the intervening decades, substantial work has focused on urban ES (Hubacek and Kronenberg, 2013). For example, Calvet-Mir et al. (2012) looked at ES provided by urban gardens, while La Rosa and Privitera (2013) created an analytical framework for protecting and enhancing urban ecosystems. However, many of these topics remain divorced from the practice of planning, as 
well as from efforts to modify the processes through which planning decisions are made.

Although significant work has only looked at ecosystem service concepts in planning and urban decision-making in the last five years, and almost entirely in England and Western Europe (Albert et al., 2014a; Wilkinson et al., 2013), the research and design literature (e.g. Benedict and McMahon, 2006) have focused on promoting landscape ecology concepts, such as integration, spatial connectivity, multi-functionality, and scale, as integral elements for enhancing what green infrastructure can deliver in urban landscapes. de Groot et al. (2010) notably discuss the challenges of integrating ES into landscape planning, management, and decision making, finding definitional, classification, quantification, and valuation problems around ES. More European synthesis of ES into planning can be found in the 2011 UK National Ecosystem Assessment (2012), which delves into numerous aspects of urban ES identification, delineation, economic valuation, and case studies of ES use for decision making.

More recently, Wilkinson et al. (2013) performed a longitudinal study of plans in Stockholm and Melbourne, finding that many ES (even when not explicitly mentioned) were left out of the planning discourse throughout their study period (1929-2010). They suggest that an explicit ES approach could improve strategic plan quality by clarifying the nexus of ecological dynamics and human actions across many ES. Such a framework could also improve dissemination of planning information between cities and include insights from studies about non-urban ES. The follow-on phase of the UK National Ecosystem Assessment (UK NEA, 2012) has developed numerous techniques for enumerating ES of concern at local levels, as well as a variety of tools for ES assessments throughout Great Britain. Fürst et al. (2014) created an innovative score card for addressing questions around the effectiveness of ecosystem service frameworks for planning purposes. Using a scoring matrix similar to that of many plan quality evaluations (e.g. see Berke and Godschalk, 2009; itself a follow on to Lichfield's (1960) original work), an ecosystem service framework helped determine advantages and shortcomings of the practical use of ES for involving stakeholders in environmental planning decisions.

In the U.S. context, studies connecting ES to urban planning have primarily focused on specific projects, such as ecological restoration in the Catskills mountains to reduce water treatment costs for New York City (Appleton, 2002) or on specific aspects of planning, such as LEED green building certification (Steiner, 2014). Ahern et al. (2014) recognized this limitation, arguing for a "safe to fail" adaptive urban design framework, which integrates scientific insights with stakeholder participation and professional planning practice. Work by Young and McPherson (2013) and (2013) also examined the role of the public sector and NGOs in providing GI in the form of large-scale domestic tree planting initiatives. In perhaps the most comprehensive US-based analysis, Jantz and Manuel (2013) studied the ecosystem service implications of varying growth pressures, yielding major implications for spatial heterogeneity in ES tradeoffs, zoning regulations, infrastructure and protected land investments, and involvement by community groups. However, like most other work in this area, ES analysis was viewed as a simple, limited input into the urban decision-making process, rather than being seen as a systems-focused pathway towards an entirely new approach to stormwater planning.

\section{A framework for connecting ES and stormwater management}

Leveraging ES using GI may offer promise in addressing many of the challenges facing cities and city planning (BenDor and Doyle, 2010; Chan et al., 2006; Ervin et al., 2011; Franklin and Halsey, 2011). We are not suggesting that ES concepts are a panacea to the myriad challenges facing infrastructure management in cities (Norgaard, 2010). Instead, we argue that the nascent applications of ES in urban policy (primarily the result of natural capital valuation research; Gómez-Baggethun and Barton, 2013; Guerry et al., 2015) have created an interest in using ES frameworks to evaluate tradeoffs between alternative stormwater management actions or scenarios (Franklin and Halsey, 2011; Fürst et al., 2014). Understanding stormwater infrastructure through the lens of ES represents an expansion of the social-ecological-infrastructural systems (SEIS) framework developed by Ramaswami et al. (2012, Pg. 801), which acknowledges that sustainable urban infrastructure rests on "...complex, cross-scale interactions between the natural system, the trans-boundary engineered infrastructures, and the multiple social actors and institutions that govern these infrastructures."

We argue that ecosystem service- and disservice-based assessments must focus on those additional services (e.g., cultural preferences, recreation, health; e.g. Hernández-Morcillo et al., 2013) that may be significantly changed by planning alternatives, and which are of importance to the community. BenDor et al. (2017) have produced a detailed conceptual framework that can be adapted to guide evaluations for providing insight into the thoughtful, balanced use of stormwater infrastructure to incorporate ES that are desired, appropriate, and useful in multiple ways. They argued that this conceptual model could aid the ongoing discussion about identifying measurements - both quantitative and qualitative - and metrics that can help practicing planners, engineers, and other natural resource professionals to work together to assess the extent to which stormwater infrastructure can benefit community, ecosystem, and regulatory needs.

Their conceptual framework starts on the left of Fig. 1, where stormwater and ecosystem inputs into the facility or network (e.g. water, heat, nutrients, pollutants, pathogens, and microbial, flora, and fauna fluxes) are met with a number of possible infrastructure arrangements, whose functions, resulting services, and eventual values (weighted by their costs) can either be evaluated entirely based on their production of traditional stormwater services (e.g. flood retention, conveyance), or by an expanded set of ES (e.g. habitat provision, infiltration, nutrient removal).

Both sets of services can be weighted using (1) the relative values expressed by the community and (2) the costs of marginal services provided by the change in infrastructure, yielding the relative wellbeing (a holistic cost-benefit ratio; "W") produced by a given infrastructure scenario (patches or networks of SCMs, GIs, etc.). Scenario or alternatives analysis of a given infrastructure system (both engineered and/or nature based; left side inputs) would now incorporate an expanded suite of services provided by the proposed changes in infrastructure, as weighted by stated community values ("V", right side inputs).

\subsection{Assessing community values}

The basic notion that a community can possess or articulate a coherent set of rank-ordered values is frequently challenged in theory and practice. This is important as many ES values are not pre-formed in people's minds and traditional surveys may only highlight individual, utilitarian values. In western Europe, where ES-based planning frameworks have gained a foothold, great interest has fallen on how community values are deduced, and who is involved in value deduction (e.g. UK NEA, 2012). Significant work has begun to explore measures of ES-derived community wellbeing based on community values expressed jointly in public planning and policy processes, such as community meetings, visioning processes, surveys, focus groups, interviews (Balram and Dragićević, 2005; Barkmann et al., 2008; Kaźmierczak, 2013).

However, aggregating individual and immediate responses to inquiries (e.g. surveys, interviews) about ES values can miss out many "softer" values, such as those that are more deeply held or are shared by communities and emerge only through deliberation. One example of this is the violent public reaction witnessed when the UK government attempted to sell publicly-owned forest assets (Carrington, 2012). Although it is not our intent to provide a thorough overview of valueelicitation techniques here, we should note that there is considerable 


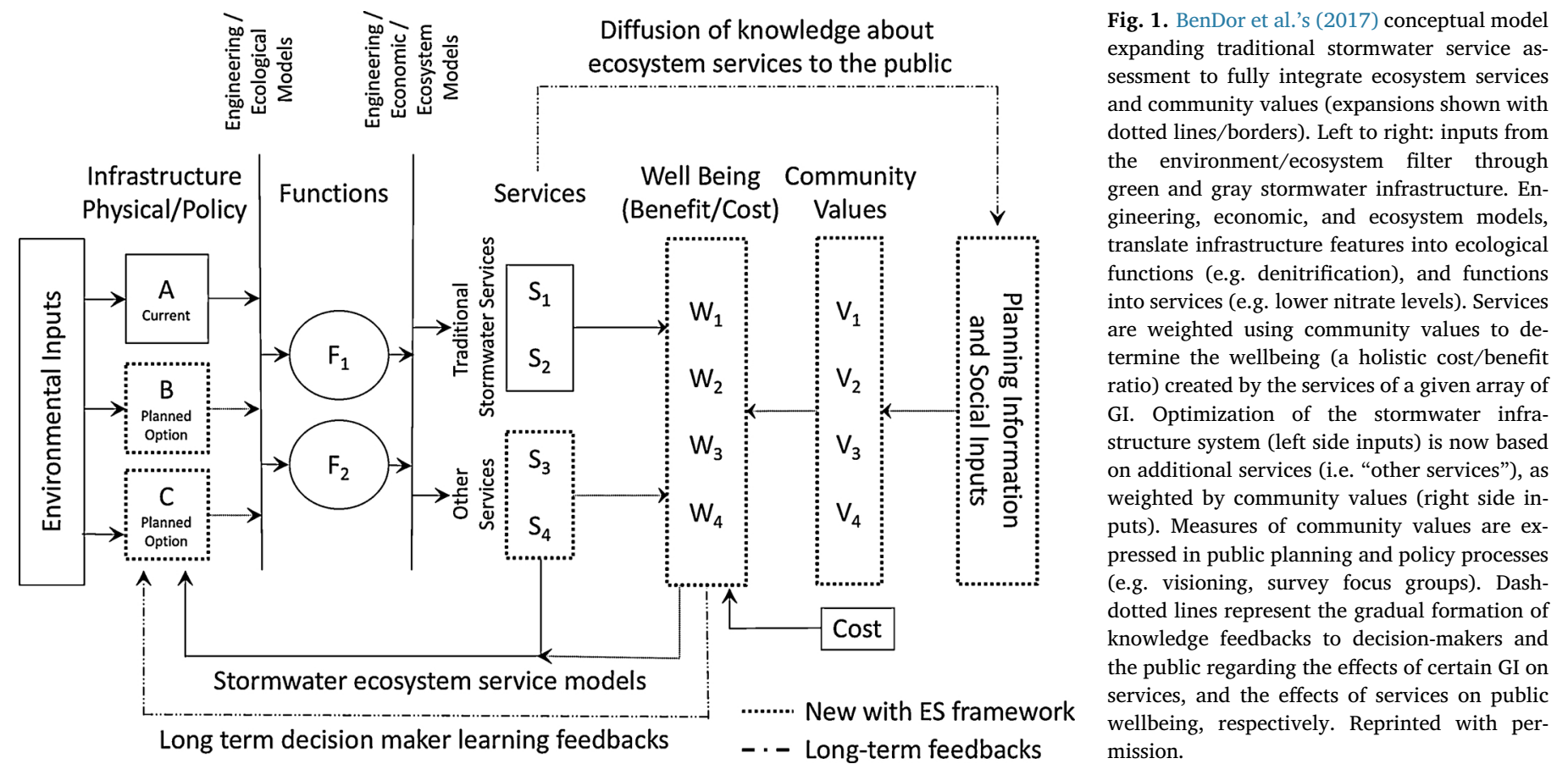

literature on the use of multi-criteria decision analysis (MCDA) and other frameworks for assessing quantifiable and non-quantifiable preferences and values into decision-making frameworks, which could be extended to include holistic values of urban ES (Bojórquez-Tapia et al., 2005; Mendoza and Martins, 2006; La Rosa et al., 2016; Plieninger et al., 2015).

There may be different approaches for incorporating a broader range of ES into stormwater planning, and these approaches will likely differ based on how one uses scenario analysis (e.g. see Hopkins and Zapata, 2007). For example, practicing planners may explore a series of infrastructure options, analyzing ways to maximize a most-desired ecosystem service, while iteratively adding additional services to assess. However, a potential concern is that planners will articulate services narrowly and pre-select 'important' services, which can blind them to the potential externalities for other services and beneficiaries (we address this later in our suggested research agenda).

The development of these planning processes and use of ecosystem assessment tools must draw on measured aspects of human wellbeing to identify potentially significant services or disservices. This requires (1) a process to assess community values and identify the relationships between infrastructure options, ecosystem service outputs, and resulting community wellbeing, and (2) a process to consider expert knowledge and local information (see discussions of expert knowledge elicitation in Reed, 2008 and Ford and Sterman, 1998).

During participatory planning processes for stormwater management decisions, plans can articulate the values of a community (Godschalk, 2004). Public participation throughout the planning process (including visioning processes; see Condon, 2012; Shipley (2002); Shipley and Newkirk (1998)) elicits the goals and objectives for a community's stormwater infrastructure. While these goals typically include meeting regulatory requirements at the federal, state, and local levels, they also often include statements about water quality, flooding, safety, cost-benefit requirements for new infrastructure, habitat impacts, or other factors valued by the community. Although significant work in the participatory planning literature discusses expert knowledge elicitation (e.g. Shmueli et al., 2008; Susskind and Landry, 1991), only recently has work begun to explore the use or prioritization of community values in an ecosystem service context (Albert et al., 2014a; Daniel et al., 2012). In the section below, we use two cases to apply
BenDor et al.'s (2017) framework (Fig. 1) to examine opportunities for trade-offs among different stormwater infrastructure options.

Our approach differs from earlier conceptualizations of stormwater infrastructure in four ways:

(1) we provide an explicit link to the communities within which facilities and networks are placed;

(2) we search for potential for win-win (i.e. cheaper and better) scenarios, while envisioning multiple system tradeoffs that can present different benefits and challenges during the planning, design, and implementation processes (e.g. see more general work on urban ecosystem service tradeoffs by Dorning et al., 2015);

(3) the use of a multi-criteria approach to services and disservices allows planners and stakeholders to weight the relative values for each of the criteria; and

(4) this approach would present the opportunity for iterative dialogue among those involved.

\section{Case studies}

Several cities have established techniques for integrating gray and green stormwater infrastructure; we draw on two examples - the South Ellerbe Wetland in Durham, North Carolina and the Tabor to the River (T2R) green infrastructure plan in Portland, Oregon - to illustrate how the use of ES changes the evaluation of benefits accruing from different stormwater infrastructure scenarios. While these cases are exemplary of cities that currently employ extensive green and gray infrastructure, they also represent wildly differing historical and legal contexts, motivations for implementing GI, hydro-climate regimes, methods of incorporating public input into the stormwater infrastructure decisionmaking process. These differences make them ripe for exploration as case studies of GI implementation and decision-making.

\subsection{Durham, North Carolina}

Durham is a rapidly gentrifying, former industrial city in central North Carolina, which faces stormwater quality challenges as a result of its own recent growth, as well as that of its upstream neighbors (e.g. Greensboro, NC). The northern half of Durham, including much of the 
A.

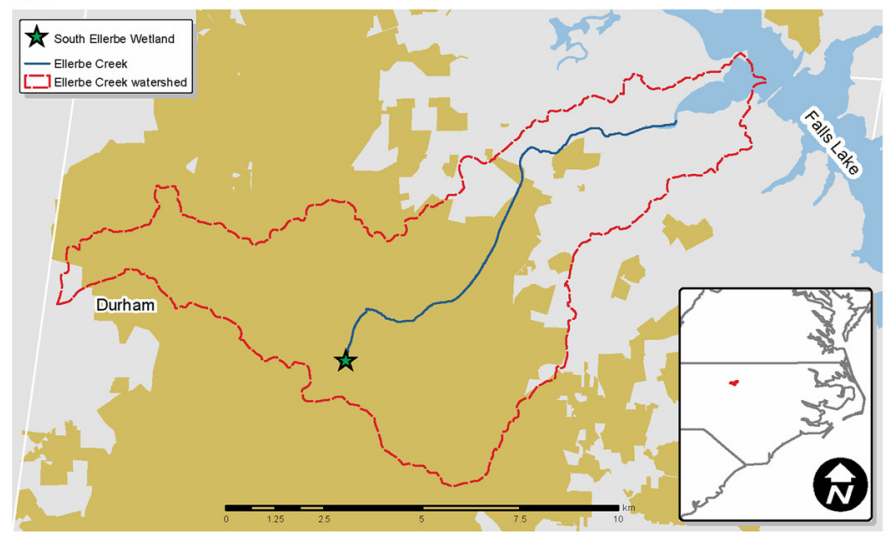

B.

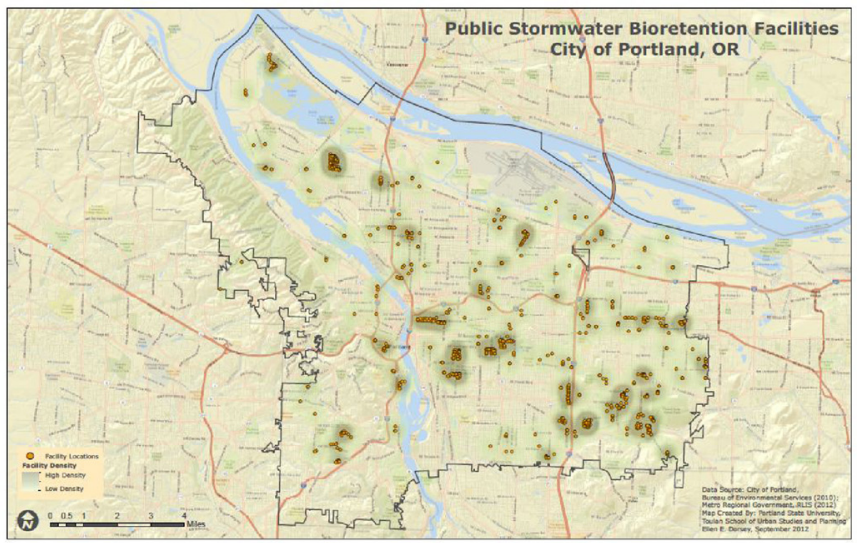

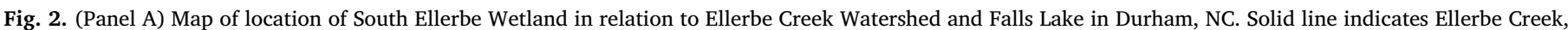

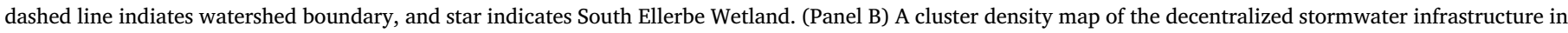
Portland Oregon.

downtown area, is drained by Ellerbe Creek, which flows into Falls Lake, a flood control, water supply, and recreation impoundment that was completed in 1983. In 2011, the State of North Carolina adopted the Falls Lake Nutrient Management Strategy (15 A NCAC 02B.0275) to reduce nitrogen and phosphorus pollution to Falls Lake from new and existing development, wastewater treatment plants, and agriculture.

Under these regulations, expensive flood mitigation and water quality improvement structures would be required in order to repurpose the abandoned Duke Medicine Diet and Fitness Center, a nowpublicly owned complex that sits in a 100-year floodplain in a rapidly growing part of western Durham (Fig. 2A). While this site currently includes some green space in the form of an athletic field, much of this space is fenced off and unusable due to frequent flooding, the result of the progressive failure of the concrete culvert carrying the now-buried stream.

To frame this case within BenDor et al.'s (2017) conceptual approach, we can observe that there were a series of potential infrastructure options for moving forward, each of which would have different ES impacts that would interact with community values and preferences, increasing or decreasing the well-being of different constituencies, including neighboring employees, surrounding residents, or downstream populations. While preparing to decide the site's stormwater future, Durham Stormwater Services staff collaborated with the City-County Planning Department to solicit feedback during 12 public meetings over four-months from nearby residents and community groups including the Durham Open Space and Trails Commission and the Durham City-County Environmental Affairs Board (Sandra Wilbur, PE, Durham Stormwater Services, personal communication; Durham Stormwater Services, 2017). We can frame this community input process as a technique for preferentially ranking the ES that would be produced by stormwater retrofits (Fig. 1).

Rather than pre-determining the ES of concern, stakeholder feedback was gathered as a means for evaluating the outcomes of different decisions; a frequently-asked questions document later produced by Durham Stormwater Services (City of Durham, 2012a) was informed by citizen feedback and reflects important community values related to stormwater infrastructure. The key community values expressed in this document, and addressed in the design of the project were: 1 ) concern over capital and maintenance costs and overall cost-effectiveness of stormwater infrastructure; 2) desire to provide co-benefits such as community amenities as part of stormwater infrastructure development (e.g. providing seating and viewing areas, as well as improved access to the nearby South Ellerbe Creek Trail); 3) concern over unintended consequences of stormwater infrastructure, such as providing habitat for nuisance species (e.g. Canada geese [Branta canadensis] and mosquitos [e.g. Culiseta longiareolata]); and 4) broader sustainability concerns related to preserving the existing building on site if possible, and reusing and recycling demolished building materials in the case that the building could not be preserved (it was later determined that the building could not be preserved due to wetland sizing requirements and FEMA floodway regulations).

Based on this community feedback, as well as Phase I and II site assessments that determined sub-surface and surface physical conditions and constraints (e.g. requirements for removal of all present infrastructure and impervious surface), Durham Stormwater Services evaluated four different types of stormwater retrofits for the site and the 196-ha of existing development in and around the downtown area (Brown and Caldwell, 2012). These options included alternative arrangements of wet ponds, constructed wetlands, bio-retention sites, or a single 3.6-ha constructed wetland (Table 1).

Using hydrological and ecosystem service models, the 3.6-ha wetland was estimated to achieve the same nutrient reduction benefits as 36 wet ponds $(\$ 18 \mathrm{M}), 17$ constructed wetlands $(\$ 18 \mathrm{M})$, or 500 bioretention sites $(\$ 18 \mathrm{M})$, at only $26 \%-44 \%$ of the cost (Table 1 ; City of Durham, 2012b). However, space was a major constraint that limited the use of distributed sites in this manner, as urban land uses currently 103-ha of the-196 ha site. After evaluating citizen input and relative costs for each option, the city chose the constructed wetland option, and is now planning for the South Ellerbe Wetland project, which would cost roughly $\$ 8$ million USD to construct, with a projected yearly maintenance cost of $\$ 40,000$, including regular trash removal and replanting.

After narrowing the project scope to the Ellerbe Creek Wetland, the City's design process has involved continued public meetings and stakeholder input. An early 2017 indicated that improving water quality in

Table 1

Summary of alternatives to reduce nitrogen loading by $225-450 \mathrm{~kg}$ s annually, and phosphorus loading by $55-130 \mathrm{~kg} \mathrm{~s}$ annually in Durham, NC case study. Adapted from City of Durham (2012b).

\begin{tabular}{llll}
\hline Alternative & $\begin{array}{l}\text { No. of } \\
\text { sites }\end{array}$ & $\begin{array}{l}\text { Total lifetime } \\
\text { cost (est.) }\end{array}$ & Co-benefits/Disservices \\
\hline South Ellerbe Wetland & 1 & $\$ 8$ million & $\begin{array}{l}\text { Seating and viewing areas; } \\
\text { improved trail access; educational } \\
\text { signs / nuisance animals }\end{array}$ \\
$\begin{array}{l}\text { Wet ponds } \\
\begin{array}{l}\text { Constructed wetlands } \\
\text { Bio-retention sites }\end{array}\end{array}$ & 17 & $\$ 18$ million & $\begin{array}{l}\text { Unclear } \\
\text { Potential for educational signs } \\
\text { Potential for educational signs }\end{array}$ \\
\hline
\end{tabular}


Ellerbe Creek remained a primary goal in the area. Additionally, residents indicated that amenities, such as trails (91 percent of respondents), boardwalks (85 percent), seating areas (76 percent), and other educational features (e.g. signage; 90 percent) were important parts of any new stormwater management design (Wilbur et al., 2017) Per a July 2017 press release (Blalock, 2017), Durham has endeavored to take this feedback into account in its design process:

[Quoting project lead] "The project team has shaped this design workshop based on public input we've received so far.... We had a great response to the first public session and survey. Now, we want to take an in-depth look at some of the ideas that could enhance the site and make it a premiere restoration project and asset for Durham." [...] The City welcomes input on what people would like to see incorporated into the final design, such as site amenities. [...]

Taking a critical view, it is important to note that this is not a perfect example of an ES approach; for example, while community input was elicited through surveys and an array of public meetings and interactions, it is not clear that all citizen perspectives were incorporated and that the City's approach to evaluating infrastructure alternatives was systematic and comprehensive. For example, the city never explicitly created a reasonably comprehensive list of ecosystem services and disservices created by each option, which would have been key to determining potential tradeoffs and unintended side effects of each infrastructure choice. Nevertheless, the participatory processes that led stormwater decisions to converge towards the South Ellerbe Wetland project, as well as more recent and specific design processes for this wetland (CITE), still represent an important archetype of a systems-oriented, ES framework for GI development. Durham's process was explicitly driven by an evaluation of different services created by proposed scenarios, the (sometimes non-intuitive) values of community members, and the strengths and limitations of ES to meet stormwater management goals in a cost-effective manner (Fig. 3). This case study speaks towards improvements that can be made in ES evaluations and alternatives analysis prior to infrastructure construction.

\subsection{Portland, Oregon}

In our second case study, we take a retrospective examination of a GI initiative in Portland, Oregon, where we view post-construction lessons about GI through the lens of our conceptual framework. Unlike the Durham example, the Portland case offers several alternative perspectives on enabling storm water infrastructure in a city that is highly developed, though contains quickly degrading infrastructure. In addition, the long history of experimentation with green infrastructure in the Pacific Northwest (see for example: Booth and Jackson, 1997; and Horner, 1988) offers a perspective of a mature system, along with the many lessons that have been gained in developing alternative stormwater systems over the past three decades.

Yet, despite the reputation that Portland has received in urban sustainability rankings of the past decade (e.g. Greenbiz, 2008; Sustainlane, 2006) and in the popular media (Harney, 2011; Revkin, 2008), the city was under major scrutiny for exceeding water pollution discharge limits throughout the 1990s (Shandas and Messer, 2008). After notable legal battles and negotiations around its combined sewer system, the City built on numerous studies around stormwater detention to develop a 20-year plan to reinvent its stormwater system by replacing degrading pipes (City of Portland, 2005). Rather than removing concrete from city streets and replacing all the degrading pipes, city managers examined the feasibility of using GI to complement the replacement of pipes. Based on extensive analysis of fiscal, functional, and design assessments, the City completed a 20-year plan (in 2013), and put in place a fully integrated green- and gray-infrastructure system, though with a major focus in one part of the City.

One part of the city, namely "Tabor to the River" (T2R; City of Portland, 2012), has been the first to see a fully implemented graygreen integration (see Fig. 2B). As the largest fully integrated green and gray neighborhood infrastructure project in any one part of a city, the Portland T2R rollout represents a significant alteration of the biophysical landscape. Although the entire process was facilitated by the Bureau of Environmental Services, whose primary responsibility is the management of sewer and stormwater in the city, several other municipal bureaus, including transportation, planning, and water were intimately involved in the process.

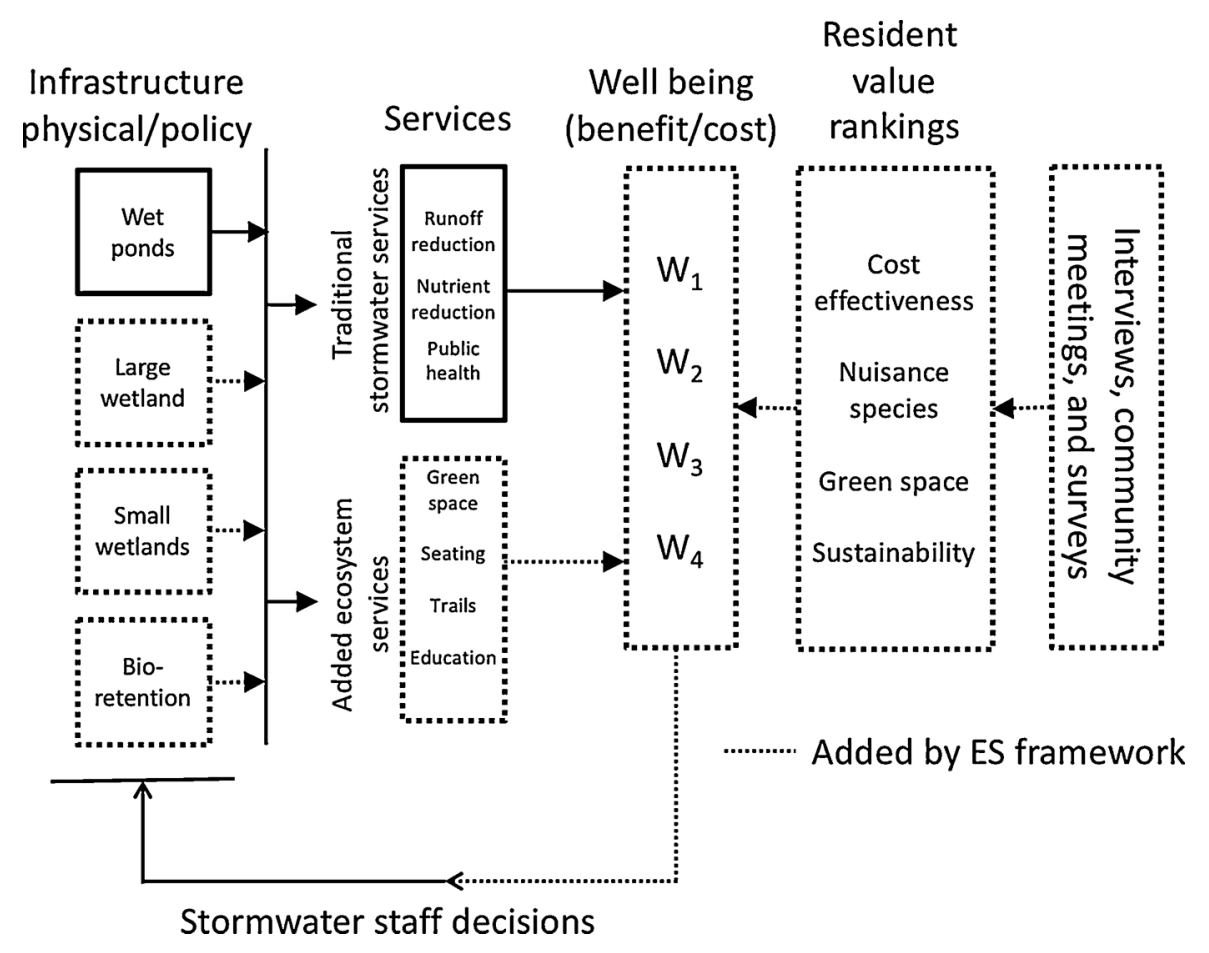

Fig. 3. Application of BenDor et al.'s (2017) analytical framework to Durham, North Carolina case study of the South Ellerbe Creek Wetland. 
Together, these agencies conducted technical assessments of the physical infrastructure that would be replaced by gray and those areas where GI may be more effective. However, it is very important to note that these assessments did not involve public participation and did not explicitly take into account community values. Instead, community values were assessed as part of a concerted effort to engage with citizens as the GI was being placed in the T2R part of the city. Community engagement came in the form of surveys that were sent to residents surrounding the existing and soon to be implemented areas of the T2R (Shandas et al., 2012). Specifically, these surveys aimed to understand community values about the neighborhood, and the qualities that may change as a result of GI implementation. To do this, the Bureau of Environmental Services surveyed neighborhoods where GI had been operating for several years, where GI had been recently installed, where GI was about to be installed, and two 'control neighborhoods,' where direct implementation of GI would not happen as part of the T2R program.

The results of these surveys indicated that respondents in neighborhoods with established GI were more likely to identify aesthetic improvements and stormwater infiltration ES as part of the GI than those that did not live near similar facilities. Additional surveys found that the public viewed green stormwater facilities as producing a greater diversity of high quality of ES than conventional systems (Netusil et al., 2014; Shandas, 2015; Yeakley et al., 2011). Based on the increased vegetation within the green stormwater facilities alone, managers and residents both cited improvements in thermal regulation, aesthetics, and improvements in traffic safety. These community values for GI suggest that stormwater management may offer a means to engage residents in environmental planning within their neighborhoods. Additionally, the results were instrumental in identifying the added benefits (and challenges) associated with GI at the neighborhood scale. Portland's assessments, performed after infrastructure provision, can now be used by the city to inform later infrastructure provision.

\subsection{Durham-Portland case study synthesis}

Our two case studies offer vastly different perspectives on decision making around GI; while Durham has separate sewer and stormwater systems, Portland has been forced to consider GI in the face of lawsuits around its combined sewer system. In places where overflow of untreated sewage has historically been an issue (e.g. Portland BES, 2017), the cost savings offered by GI - as an alternative to costly underground detention investments - may be one of the strongest cases for its adoption. However, Durham has its own challenges; the Falls Lake Nutrient Management Strategy (15 A NCAC 02B.0275) forced the city to consider GI and the non-traditional stormwater ES that they produce in their infrastructure decisions.

It is evident from each of these cases that the ways we account for, and ultimately monetize, ES can play a significant role in making a fiscal case for GI that speaks directly each city's "bottom line." This is a new arena for land value capture (Medda, 2012), which in this case concerns how much aesthetic values of GI (e.g. enhanced tree canopy, small parks with stormwater management capabilities, roadside infiltration features that increase neighborhood walkability, etc.), can quantifiably impacts on property values and returns to a local property tax base. Additionally, land value capture concerns potential ways in which GI could increase incentives for private capital re-investment (e.g. central city revitalization; Rohe, 2009). In the Durham case, the centralized wetland may have been more "cost effective," but it is important to consider how street greening, neighborhood pocket park creation, and distributed infiltration alternatives might have actually generated more reinvestment (particularly in distressed neighborhoods).

Durham and Portland are two examples of GI decision processes that reflect the right side of BenDor et al.'s (2017) conceptual framework (Fig. 1), which concerns the alignment of community values with infrastructure projects. In the Durham case, alternative infrastructure configurations were weighed prior to implementation by comparing ES produced by each alternative with the community values for those services. In the case of Portland, the neighborhoods undergoing infrastructure changes were determined, after the fact, to have become receptive to seeing green solutions, a value generally held by the residents (Shandas et al., 2012). These are important lessons for any future GI implementation efforts in Portland, and indicate a pathway for social learning as residents come to recognize multiple benefits derived from their experience with GI projects. Unlike Durham, where we already see explicit consideration of resident values in GI development, time will tell how the recognition of those benefits can influence the decisionmaking process used to plan or develop stormwater infrastructure projects. While these contextual differences may have played a strong role in driving these decision-making processes, the integration of community values was an essential part of each planning process.

In light of these two vastly divergent case studies, we have endeavored to identify a series of applied research needs that will help stormwater planners and managers around the world understand their stormwater needs and identify instances where urban GI could generate multiple benefits for their communities. Since many cities are rapidly integrating GI and more are developing plans to do so (Flynn and Davidson, 2016; Wise, 2008), systematic approaches need to develop a body of evidence demonstrating how GI efforts succeed or fail in providing ES and improved stormwater management.

\section{Discussion and call for research}

Ecosystem service-based approaches to stormwater management represent a strategic and systemic shift in the determinants of stormwater infrastructure and design choices. Much of the stormwater literature is focused on increasing infiltration rates and pollutant removal functions for pollutants like phosphorus and sediment removal (Burns et al., 2012). We propose a shift in the way that stormwater infrastructure choices are made by considering the many additional benefits and disservices of GI, which may facilitate more comprehensive, inclusive decisions about whether to use GI, how much, and which types. By using ES as a broadly-based evaluation system, we can begin to elaborate multiple benefits and multiple costs (including tradeoffs) that may accrue to a community (Lovell and Taylor, 2013; Viglizzo et al., 2012) that go beyond narrow, engineering-based conveyance and treatment functions.

Unfortunately, such considerations remain undeveloped; first, research in the US is needed to address critical questions about 1) the advantages and disadvantages of GI, including adequacy, biophysical constraints, maintenance and operation costs, 2) the relationships and interactions among different infrastructure options, ES, and the preferences of stakeholders and communities for different stormwater infrastructure, 3) long-term effects on ecosystem structure and function, especially regarding the predictions of system trajectories over time, 4) the need for new frameworks to facilitate effective collaboration between different disciplines, professions, and communities (e.g. following the lead of international organizations like the UK Construction Industry Research and Information Association's Sustainable Drainage Systems [SuDS] manual; Woods-Ballard et al., 2007). We delineate this research along five different dimensions that aim to provide guidance for researchers to support the emerging discourse on integrating green and gray stormwater infrastructure.

\subsection{Dimension 1: stormwater infrastructure under a systems approach:} understanding the coupled and scale-dependent effects of non-structural (policy) and structural stormwater management techniques

Stormwater management is typically applied locally to each building or development site. While such an approach is consistent with the legal framework underpinning urban development in general, 
hydrologic sciences recognize that water is linked through overland and underground flow networks (Band et al., 2014; Kaushal and Belt, 2012; Miles and Band, 2015). As a result, a fix at one location may not provide system-wide improvements and may instead cause downstream harm (Bernhardt and Palmer, 2011), unless a systematic application of facilities as functional networks is used. To that end, further research must determine how networks of GI across different scales interact to produce or deplete ES at the local or landscape level (see Crossman et al., 2013). What types of interactions occur between site-scaled GI and watershed-scale impacts of GI networks? This is an on-going question in the stormwater engineering literature (e.g. WEF/ACSE, 2012).

Furthermore, what types of non-linear interactions emerge from a network of GI? Is the whole of the network greater than the sum of the parts? Since GI networks will be ecological patches of semi-engineered facilities in the urban mosaic, the theories and science behind landscape and systems ecology can play an important role in the planning and designing process (Levin and Mehring, 2015; Mitsch, 2014; Trabucchi et al., 2012; Winemiller et al., 2010). Programmatic and landscape scale approaches to environmental management are also advancing rapidly in the regulatory sphere - for example, species or habitat mitigation (Clement et al., 2014; Kiesecker et al., 2010) - and may provide useful models or approaches for integrating biodiversity and stormwater related services.

5.2. Dimension 2: appropriate infrastructure for time and place: identifying the adequacy of current and future generations of stormwater management techniques for meeting future stormwater needs

The practice of planning involves multiple considerations, including defining GI as it relates to stormwater services for a given bioregion, climate, topography, and characteristics of the built environment. ES vary with climate the geographic context of stormwater infrastructure; to what extent are GI approaches suitable in varying climate and micrometeorological conditions, such as urban heat island effect, different rainfall intensities, evapotranspiration patterns, and dry-wet cycles? Inevitably, certain climatic regimes will make GI more, or less, practical. For example, Florida and the Southeastern US have different GI needs (e.g. high water tables, short but intense thunderstorms, and less frequent but high rainfall volume tropical storms) than the Pacific Northwest, which receive more frequent but low-intensity storms. Semi-arid climates have infrequent rainfall and long dry periods, and so pose new research challenges for the design of infrastructure and GI networks (Hale et al., 2015).

An extensive literature now investigates the use of GI in dry (xeric) environments (Houdeshel et al., 2012; Larson and Grimm, 2012; Zhu et al., 2004). Low-rainfall environments, for example, may create more tractable opportunities for GI if bio-retention facilities operate disproportionately well with relatively low precipitation. Conversely, these facilities may become inefficient if the environment becomes so dry or erratic (i.e. infrequent, intense storms) that vegetation maintenance becomes difficult and requires active management (e.g. watering, vegetation maintenance, emergency maintenance to prevent damage during extreme storm events). Further research will need to evaluate the acceptance of GI by stormwater engineers and the professional community, political institutions, and the public at large.

Research will also need to evaluate the production of ES by stormwater infrastructure as it interacts within the variable and heterogeneous socio-ecological landscapes of the urban metropolis (e.g. the urban-rural gradient; Maestas et al., 2003; McDonnell and Pickett, 1990; McDonnell et al., 1997; Pickett et al., 2011). Such an approach could involve delineating a multivariate gradient from highly impacted urban environments to pristine or natural environments, with consideration of climate, hydrologic, sociological, and economic conditions to characterize ES within an array of gray and green stormwater infrastructure options.
Finally, we must consider the full range of scales in which GI exists, for these may well affect their functioning and long-term character. For example, to what extent does higher density development alter the effectiveness of GI networks? This 'building up' approach would not only minimize rooftop impervious surfaces, but also would present novel GI opportunities like urban forestry solutions, green roofs, living walls, and runoff reuse. Alternatively, to what extent does a low-density 'sprawl' approach to urban development enhance the opportunity to provide run-off control or water quality improvements using GI (e.g. Stone and Bullen, 2006)? All of this research must be communicated to inform planners and local officials about the types GI projects might work best in different settings.

5.3. Dimension 3: develop credible and replicable methods that can estimate the supply and flow of ES from landscape processes and stormwater management techniques at spatial scales pertinent to urban and regional planning (i.e. parcel, neighborhood, catchment, watershed, metropolitan, and basin scales)

How can city planners, engineers, and other natural resource managers, work with stakeholders to rigorously evaluate the relative benefits of nature-based approaches to managing urban stormwater? Methods that function at multiple spatial scales are imperative to understanding the tradeoffs created between upstream and downstream service provisions (e.g. Kousky et al., 2013; Scholes et al., 2013). For example, rapid conveyance of stormwater through a well-designed drainage network produces large amounts of flood prevention services, yet can increase flooding downstream, thereby simply shifting the flow of ES spatially. Andrew et al. (2014) describe techniques for using remote sensing to directly gauge ecosystem service delivery throughout an urban region, leading to better spatial characterization of ES by planners.

These methods must also be able to include non-traditional stormwater services, such as habitat provision, disease prevention, or aesthetics. In large part this involves creating methods that balance the information needs of an ES approach with the cost and capacity of stormwater managers and urban planning processes. Methods that require years of data collection and complex inputs vastly increase costs and reduce the likelihood of actually implementing an ES approach. Work by Frank et al. (2012) and Vaissière et al. (2013) in transitioning ES into generalizable landscape metrics is a major step in the direction of creating a system whereby information on ecosystem service tradeoffs can be readily understood and digested by practicing planners. Work in this area has produced research-grade modeling efforts (see Grêt-Regamey et al., 2013 and Petter et al., 2012), but these remain extremely complex to implement (Mascarenhas et al., 2012). TEEB (2011) details needed future steps for integrating ES into decisionmaking, generally.

One promising example of new resources to help cities access the data needed for an ES assessment is the US Environmental Protection Agencycoordinated EnviroAtlas (http://enviroatlas.epa.gov/enviroatlas/atlas.html), which launched in 2014. It is an open access online resource with data on ecosystem processes, structures, and services for the United States, with detailed high resolution data collected for half a dozen cities including Durham NC and Portland Oregon, and with data collection for additional cities underway. Other data-rich systems for assessing impacts on endangered species and other natural resources include NatureServe Explorer (http://explorer.natureserve.org/) and Surveyor (https://surveyor.natureserve.org/), as well as the US Fish and Wildlife Service's Environmental Conservation Online System (ECOS; USFWS, 2015a, b) and Information, Planning, and Conservation System (IPaC; USFWS, 2015b). Additionally, US Environmental Protection Agency's Final Ecosystem Goods and Services Classification System (FEGS-CS; USEPA, 2013a) establishes a strong framework for categorizing ES. 


\subsection{Dimension 4: develop techniques for quantifying and prioritizing community values for ES}

Few studies have explicitly considered community values in assessing ES for urban planning, although an emerging literature suggests many opportunities (Albert et al., 2014b; Costanza et al., 2011; Daniel et al., 2012; Shandas, 2015). To do this, methods developed by economists (Freeman, 2003; Just et al., 2004) and decision scientists (Clemen and Reilly, 2001) to explore synergies and tradeoffs emerging from stakeholder discussions will need to be adapted for use in urban planning. This will also need to draw on techniques developed by social scientists and practitioners (e.g., Brown et al., 2012; Cowling et al., 2008; Wilson and Howarth, 2002) for assessing stakeholder perceptions (Schaich, 2009) and engaging community members in identifying and prioritizing ecosystem benefits (Palacios-Agundez et al., 2014; Sitas et al., 2014).

One pathway to explicitly integrating community values involves using plan analysis techniques to understand direction setting efforts for goals, objectives, and recommended policy actions as proxies for public values (e.g. Berke et al., 2006). An extensive literature looks at the relative quality of plans based on quantitative metrics that can include expressions of community values, needs, and goals (Berke and Godschalk, 2009). Additionally, a broad literature has begun to explore the interface of planning and public participation, whereby articulated community desires and actions are quantitatively coded (Patton, 2001) into explicitly prioritized "Community Values." Additionally, data included in this process may include projections of demographic trends, which may indicate how community values and needs will change over time (see UK National Ecosystem Assessment 2012 for process developed for use in England).

\subsection{Dimension 5: develop techniques for integrating community values for ES (derived in Dimension d 4) into the stormwater planning process}

Does ecosystem service optimization (i.e. maximizing range or amount of certain ES or sets of ES) conclusively lead to a better wellbeing for urban residents? If improving wellbeing is our objective, then what role could ES play, specific to stormwater management? What is the relationship within the planning process of community "wellbeing" and other aspects and dimensions of "community value?" How would using an ES framework improve or change the outcomes and sustainability of urban environmental planning processes? Unfortunately, Opdam (2013) concludes that the scientific state of ecosystem service assessments and their ability to involve stakeholders is not yet prepared to deliver the types of tools needed to support planning. Colding (2011) is equally hesitant about the potential success of using an ecosystem service framework, questioning whether it would yield better outcomes. In particular, understanding how ES are distributed between different community groups remains an un-met challenge. Significant lessons for the US can be drawn from the work of the UK's Department for Environment, Food and Rural Affairs (UK DEFRA, 2007), which created three tiers for performing assessments across the spectrum of ES, including (1) stakeholder-based semi-quantitative assessment of likely impacts of decisions across the spectrum of ES, (2) value transfer from interventions, and (3) bespoke ES valuation. DEFRA's work in this instance points a way beyond the seeming obsession with ES quantification that has stalled the use of ES in many cases (Silvertown, 2015) when it may not be necessary to make robust and transparent decisions. Moreover, the first tier's the semi-quantitative approach ensures that a systemic overview of ES impacts is taken prior to focusing limited resources on more detailed evaluation of services that emerge (but are not pre-determined) as priorities.

Currently, many academic communities are working in this area (urban planning, stormwater engineering, environmental management, physical and urban geography), with little integration (National Research Council, 2014). It will likely not be possible to address human dimensions of stormwater ES through a single tool. Instead a suite of tools (e.g. Maringanti et al., 2009) will be needed to make clean the connections between biophysical service production and community values.

Finally, could green and gray infrastructure produce co-benefits that equally address the challenges facing cities? Stated differently, to what extent can these two types of stormwater infrastructure address or fulfill broader community needs, thereby creating value for the community and increasing wellbeing? For example, gray infrastructure may only address a need for flood reduction (direct community value), yet GI may reduce flooding while addressing a broad range of additional community needs, such as improving safety (accident reduction), expanding green space, slowing traffic, expanding non-human habitat, among others. However, these co-benefits are only valuable in so far as they provide services that are acknowledged and valued by the community (Chan et al., 2012; Daily et al., 2000; Jacobs and Buijs, 2011).

\section{Conclusions}

In this paper, we posit that stormwater management infrastructure systems are complex, multi-faceted, and require the explicit integration of human and biophysical considerations. We argue that the current approach could be improved, particularly in terms of environmental outcomes, through the incorporation of a framework that focuses on evaluating the impacts of infrastructure decisions on a comprehensive set of ecosystem services produced. ES and environmental planning systems have a long history of interaction, although the nomenclature has not been the same. A focus on ES can allow planners to better understand the broader set of ecological benefits offered by stormwater infrastructure, generally, and may reveal that, when viewed in aggregate, certain GI components of stormwater systems produce a broader range of co-benefits or co-benefits that the community finds more valuable.

The important advantage of an ES framework is the opportunity to apply a systems-based approach to evaluating alternative infrastructure futures that are based on the provision of specific benefits to specific groups of people, instead of evaluating an un-coordinated list of ecological features or infrastructure components. Moreover, an ecosystem serviced-based framework could allow us to incorporate this evaluation into formal tradeoff analysis, allowing comparison across multiple desired outcomes or allowing the discovery - as we saw in our Durham case study - of win-win scenarios in which GI was less expensive and produced more desirable co-benefits than other options. Evaluating tradeoffs between infrastructure options helps to identify green-grey infrastructure assemblages that manage stormwater effectively, though perhaps not optimally, but have high rates of public acceptance, enhancing the chances of long-term stormwater management success. This may result in the use different physical designs, whether engineering or ecologically derived.

We recognize that the approach that we outline in this paper, and the specific examples that we employ, may not address the universe of infrastructure challenges facing all cities. As a result, we call for robust new areas of research into this nexus of ES and stormwater planning. Our work differs substantially from previous calls for research that emphasize urban ecological or sustainable infrastructure research (e.g. Boyle et al., 2010), in that we argue that an ES approach could represent a first step for practicing planners to evaluate the opportunities for potentially integrating GI in light of the social, ecological, and technological challenges facing cities today.

Our aim here has not been to prescribe specific uses of the framework, but rather to illustrate the process of stormwater planning and how an ES approach to considering alternative infrastructure may help to align the options for improving deteriorating infrastructure in cities with the multiple social objectives of city planning (Saha and Paterson, 2008). In light of this, it is easy to mistakenly assume that the bulk of the research agenda outlined in this article presumes a role for planners 
to identify and value services on behalf of the community, so that they can be analyzed as a technical exercise (much like economists tend to fix assumptions about value systems for the purposes of cost-benefit analyses). That approach conflicts with the idea that participatory planning efforts can use ecosystem service information to allow community members to explore and settle on the values they think most important, including different kinds of environmental values such as, but not necessarily limited to, environmental services values. We affirm the idea that a stormwater planning process that employs ES as a foundation must be participatory by design, lest it fall victim to the same historic problems generated by top-down planning processes (see Supplementary Material 1).

Stormwater planning and engineering are dynamic fields, and strongly guided research into nature based technologies and practices may open these fields to new approaches. With this evidence, the stormwater planning community may be poised to embrace ES approaches.

\section{Acknowledgements}

This work was funded by the National Academies of Science Keck Futures Initiative (NAKFI) on Ecosystem Services, as well as the National Science Foundation grants No. 1427188 (Coastal SEES) and No. 1660450 (Geography and Spatial Sciences). We would like to thank the attendees of the workshop organized in Durham, NH (October 1719, 2012) for their input, including Rochelle Araujo, Sujay Kaushal, William McDowell, and Alison Watts.

\section{Appendix A. Supplementary data}

Supplementary material related to this article can be found, in the online version, at doi:https://doi.org/10.1016/j.envsci.2018.06.006.

\section{References}

Ahern, J., Cilliers, S., Niemelä, J., 2014. The concept of ecosystem services in adaptive urban planning and design: a framework for supporting innovation. Landsc. Urban Plan. 125 (0), 254-259.

Albert, C., Aronson, J., Fürst, C., Opdam, P., 2014a. Integrating ecosystem services in landscape planning: requirements, approaches, and impacts. Landsc. Ecology 29 (8), 1277-1285.

Albert, C., Hauck, J., Buhr, N., von Haaren, C., 2014b. What ecosystem services in formation do users want? Investigating interests and requirements among landscape and regional planners in Germany. Landsc. Ecol. 29 (8), 1301-1313.

Allan, J.D., 2004. Landscapes and riverscapes: the influence of land use on stream ecosystems. Annu. Rev. Ecol., Evol. Syst. 257-284.

Andrew, M.E., Wulder, M.A., Nelson, T.A., 2014. Potential contributions of remote sensing to ecosystem service assessments. Prog. Phys. Geogr. 38 (3), 328-353.

Appleton, A., 2002. How New York City Used an Ecosystem Services Strategy Carried Out Through an Urban-Rural Partnership to Preserve the Pristine Quality of Its Drinking Water and Save Billions of Dollars Ecosystem Marketplace. New York, NY.

ASCE, 2013. 2013 Report Card for America'S Infrastructure. The American Society of Civil Engineers, Reston, VA.

Balram, S., Dragićević, S., 2005. Attitudes toward urban green spaces: integrating questionnaire survey and collaborative GIS techniques to improve attitude measurements. Landsc. Urban Plan. 71 (2), 147-162.

Band, L.E., McDonnell, J.J., Duncan, J.M., Barros, A., Bejan, A., Burt, T., Dietrich, W.E., Emanuel, R.E., Hwang, T., Katul, G., Kim, Y., McGlynn, B., Miles, B., Porporato, A., Scaife, C., Troch, P.A., 2014. Ecohydrological flow networks in the subsurface. Ecohydrology 7 (4), 1073-1078.

Barkmann, J., Glenk, K., Keil, A., Leemhuis, C., Dietrich, N., Gerold, G., Marggraf, R., 2008. Confronting unfamiliarity with ecosystem functions: the case for an ecosystem service approach to environmental valuation with stated preference methods. Ecol. Econ. 65 (1), 48-62.

BenDor, T., Doyle, M.W., 2010. Planning for ecosystem service markets. J. Am. Plann. Assoc. 76 (1), 59-72.

BenDor, Todd K., Spurlock, Danielle, Woodruff, Sierra C., Olander, Lydia, 2017. A research agenda for ecosystem services in American environmental and land use planning. Cities 60 (Pt. A (February)), 260-271. http://dx.doi.org/10.1016/j.cities. 2016.09.006.

Benedict, Mark A., McMahon, Edward T., 2006. Green Infrastructure: Smart Conservation for the 21st Century. The Conservation Fund and Sprawl Watch., Washington, D.C.

Berke, P., Godschalk, D., 2009. Searching for the good plan a meta-analysis of plan quality studies. J. Plan. Lit. 23 (3), 227-240.

Berke, P., Godschalk, D., Kaiser, E., Rodriguez, D.A., 2006. Urban Land Use Planning, 5th edition. University of Illinois Press, Urbana, IL.

Bernhardt, E.S., Palmer, M.A., 2011. River restoration: the fuzzy logic of repairing reaches to reverse catchment scale degradation. Ecol. Appl. 21 (6), 1926-1931.

Bernhardt, E.S., Band, L.E., Walsh, C.J., Berke, P.E., 2008. Understanding, managing, and minimizing urban impacts on surface water nitrogen loading. Ann. N.Y. Acad. Sci. 1134 (1), 61-96.

Blalock, Amy, 2017. News Release: Durham Seeks Stormwater Restoration Project Input. Durham, NC: City of Durham, NC. [Online]. http://durhamnc.gov/ DocumentCenter/View/16008.

Bloorchian, A., Zhou, J., McCrary, S., Boly, R., Morgan, S., 2014. Impact of site-scale Green infrastructure on volume reduction in combined sewers. In: Huber, W.C. (Ed.) World Environmental and Water Resources Congress 2014: Water Without Borders. American Society of Civil Engineers, Reston, VA, pp. 1-7.

Bojórquez-Tapia, Luis, Sánchez-Colon, Salvadur, Florez, Arturo, 2005. Building consensus in environmental impact assessment through multicriteria modeling and sensitivity analysis. Environ. Manag. 36 (3), 469-481. http://dx.doi.org/10.1007/s00267-004 0127-5.

Booth, D.B., Jackson, C. Rhett, 1997. Urbanization of aquatic systems: degradation thresholds, stormwater detention, and the limits of mitigation. J. Am. Water Resour. Assoc. 35 (5), 1077-1090.

Boyle, C., Mudd, G., Mihelcic, J.R., Anastas, P., Collins, T., Culligan, P., Edwards, M., Gabe, J., Gallagher, P., Handy, S., Kao, J.-J., Krumdieck, S., Lyles, L.D., Mason, I., McDowall, R., Pearce, A., Riedy, C., Russell, J., Schnoor, J.L., Trotz, M., Venables, R., Zimmerman, J.B., Fuchs, V., Miller, S., Page, S., Reeder-Emery, K., 2010. Delivering sustainable infrastructure that supports the Urban built environment. Environ. Sci. Technol. 44 (13), 4836-4840.

Brown and Caldwell, Inc, 2012. Technical Memorandum: Proposed Stormwater Control Measure Retrofit at Former Duke Diet and Fitness Center Site. [Online]:. City of Durham Stormwater Services, Durham, NC Accessed: 11/28/2016. https:// durhamnc.gov/DocumentCenter/View/12299.

Brown, G., Montag, J.M., Lyon, K., 2012. Public participation GIS: a method for identifying ecosystem services. Soc.Nat. Resour. 25 (7), 633-651.

Bryan, B.A., 2013. Incentives, land use, and ecosystem services: synthesizing complex linkages. Environ. Sci. Policy 27 (0), 124-134.

Burns, M.J., Fletcher, T.D., Walsh, C.J., Ladson, A.R., Hatt, B.E., 2012. Hydrologic shortcomings of conventional urban stormwater management and opportunities for reform. Landsc. Urban Plan. 105 (3), 230-240.

Calvet-Mir, L., Gómez-Baggethun, E., Reyes-García, V., 2012. Beyond food production: ecosystem services provided by home gardens. A case study in Vall Fosca, Catalan Pyrenees, Northeastern Spain. Ecol. Econ. 74, 153-160.

Carrington, Damian., 2012. Secret Forest sell-off 'Shopping lists' drawn up by conservation groups. The Guardian. Environment January 11, sec. https://www.theguardian. com/environment/2012/jan/11/secret-forest-sell-off-list.

Chan, K.M.A., Shaw, M.R., Cameron, D.R., Underwood, E.C., Daily, G.C., 2006. Conservation planning for ecosystem services. PLoS Biol. 4 (11), e379.

Chan, K.M.A., Hoshizaki, L., Klinkenberg, B., 2011. Ecosystem services in Conservation planning: targeted benefits vs. co-benefits or costs? PLoS One 6 (9), e24378.

Chan, K.M.A., Satterfield, T., Goldstein, J., 2012. Rethinking ecosystem services to better address and navigate cultural values. Ecol. Econ. 74, 8-18.

City of Durham, 2012a. F.A.Q. - Frequently Asked Questions | Proposed South Ellerbe Wetland Project. City of Durham Stormwater and GIS Services, Durham, NC.

City of Durham, 2012b. The Feasibility of a Stormwater Retrofit at Former Duke Diet and Fitness Center. City of Durham Stormwater and GIS Services, Durham, NC.

City of Portland, 2005. Bureau of Environmental Services 2005 Comprehensive Watershed ManaGement Plan.

City of Portland, 2012. Tabor to the River. Portland Bureau of Environmental Services, Portland, OR. http://www.portlandoregon.gov/bes/47591.

Clemen, R.T., Reilly, T., 2001. Making Hard Decisions, 2nd ed. Rev. Duxbury Press, Pacific Grove, CA.

Clement, J.P., Belin, Ad.A., Bean, M.J., Boling, T.A., Lyons, J.R., 2014. A Strategy for Improving the Mitigation Policies and Practices of the Department of Interior: A Report to the Secretary of the Interior from the Energy and Climate Change Task Force. U.S. Department of the Interior, Washington D.C, pp. 23.

Colding, J., 2011. The role of ecosystem services in contemporary urban planning. In: Niemelä, J. (Ed.), Urban Ecology: Patterns, Processes and Applications. Oxford University Press, Oxford, UK, pp. 228-237.

Condon, P.M., 2012. Design Charrettes for Sustainable Communities. Island Press, Washington, D.C.

Costanza, R., Kubiszewski, I., Ervin, D., Bluffstone, R., Boyd, J., Brown, D., Chang, H. Dujon, V., Granek, E., Polasky, S., 2011. Valuing ecological systems and services. F1000 Biol. Rep. 3.

Cowling, R.M., Egoh, B., Knight, A.T., O’Farrell, P.J., Reyers, B., Rouget, M., Roux, D.J., Welz, A., Wilhelm-Rechman, A., 2008. An operational model for mainstreaming ecosystem services for implementation. Proc. Natl. Acad. Sci. 105 (28), 9483-9488.

Crossman, N.D., Bryan, B.A., de Groot, R.S., Lin, Y.-P., Minang, P.A., 2013. Land science contributions to ecosystem services. Curr. Opin. Environ. Sustain. 5 (5), 509-514.

Daily, G.C., Söderqvist, T., Aniyar, S., Arrow, K., Dasgupta, P., Ehrlich, P.R., Folke, C., Jansson, A., Jansson, B., Kautsky, N., Levin, S., Lubchenco, J., Mäler, K.G., Simpson, D., Starrett, D., Tilman, D., Walker, B., 2000. Ecology. The value of nature and the nature of value. Science (New York, N.Y.) 289 (5478), 395-396.

Daniel, T.C., Muhar, A., Arnberger, A., Aznar, O., Boyd, J.W., Chan, K.M.A., Costanza, R., Elmqvist, T., Flint, C.G., Gobster, P.H., Grêt-Regamey, A., Lave, R., Muhar, S., Penker, M., Ribe, R.G., Schauppenlehner, T., Sikor, T., Soloviy, I., Spierenburg, M., Taczanowska, K., Tam, J., von der Dunk, A., 2012. Contributions of cultural services to the ecosystem services agenda. Proc. Natl. Acad. Sci. 109, 8812-8819.

de Groot, R.S., Alkemade, R., Braat, L., Hein, L., Willemen, L., 2010. Challenges in 
integrating the concept of ecosystem services and values in landscape planning, management and decision making. Ecol. Complex. 7 (3), 260-272.

Dobbs, R., Pohl, H., Lin, D., Mischke, J., Garemo, N., Hexter, J., Matzinger, S., Palter, R., Nanavatty, R., 2013. Infrastructure Productivity: How to Save \$1 Trillion a Year McKinsey Global Institute, New York, NY.

Dorning, M.A., Koch, J., Shoemaker, D.A., Meentemeyer, R.K., 2015. Simulating urbanization scenarios reveals tradeoffs between conservation planning strategies. Landsc. Urban Plan. 136 (0), 28-39.

Durham Stormwater Services, 2017. South Ellerbe Stormwater Project. Durham, NC: City of Durham, NC. [Online]:. http://durhamnc.gov/1616/South-EllerbeStormwater-Project.

Echols, S., 2007. Artful rainwater design in the urban landscape. J. Green. Build. 2, 101-122.

Ervin, D., Brown, D., Chang, H., Dujon, V., Granek, E., Shandas, V., Yeakley, A., 2011. Managing ecosystem services supporting urbanizing areas. Solutions 2 (6), 74-86.

Everard, M., McInnes, R.J., 2013. Systemic solutions for multi-benefit water and environmental management. Sci. Total Environ. 461-462, 170-179.

Everard, M., Moggridge, H.L., 2012. Rediscovering the value of urban rivers. Urban Ecosyst. 15 (2), 293-314.

Fletcher, Tim D., Shuster, William, Hunt, William F., Ashley, Richard, Butler, David, Arthur, Scott, Trowsdale, Sam, et al., 2014. SUDS, LID, BMPs, WSUD and more - the evolution and application of terminology surrounding Urban drainage. Urban Water J. 1-18. http://dx.doi.org/10.1080/1573062X.2014.916314.

Flynn, Carli, Davidson, Cliff, 2016. Adapting the social-ecological system framework for Urban stormwater management: the case of Green infrastructure adoption. Ecol. Soci. 21 (4). http://dx.doi.org/10.5751/ES-08756-210419.

Flynn, K.M., Traver, R.G., 2013. Green infrastructure life cycle assessment: a bio-infiltration case study. Ecol. Eng. 55, 9-22.

Ford, D.N., Sterman, J.D., 1998. Expert knowledge elicitation to improve formal and mental models. Syst. Dyn. Rev. 14 (4), 309-340.

Frank, S., Fürst, C., Koschke, L., Makeschin, F., 2012. A contribution towards a transfer of the ecosystem service concept to landscape planning using landscape metrics. Ecol. Indic. 21, 30-38.

Franklin, J., Halsey, K., 2011. Ecosystem services: a new approach to land planning. Or. Plan. J. (January/February), 3-6.

Freeman, A.M., 2003. The Measurement of Environmental and Resource Values: Theory and Methods. Resources for the Future Press, Washington, D.C.

Fürst, C., Opdam, P., Inostroza, L., Luque, S., 2014. Evaluating the role of ecosystem services in participatory land use planning: proposing a balanced score card. Landsc. Ecol. 29 (8), 1435-1446.

Godschalk, D.R., 2004. Land use planning challenges: coping with conflicts in visions of sustainable development and livable communities. J. Am. Plann. Assoc. 70 (1), 5-13.

Gómez-Baggethun, E., Barton, D.N., 2013. Classifying and valuing ecosystem services for urban planning. Ecol. Econ. 86 (0), 235-245.

Greenbiz, 2008. Portland Named America'S Greenest City.

Grêt-Regamey, A., Celio, E., Klein, T.M., Wissen Hayek, U., 2013. Understanding ecosystem services trade-offs with interactive procedural modeling for sustainable urban planning. Landsc. Urban Plan. 109 (1), 107-116.

Groffman, P.M., Bain, D.J., Band, L.E., Belt, K.T., Brush, G.S., Grove, J.M., Pouyat, R.V., Yesilonis, I.C., Zipperer, W.C., 2003. Down by the riverside: urban riparian ecology. Front. Ecol. Environ. 1 (6), 315-321.

Guerry, A.D., Polasky, S., Lubchenco, J., Chaplin-Kramer, R., Daily, G.C., Griffin, R., Ruckelshaus, M., Bateman, I.J., Duraiappah, A., Elmqvist, T., 2015. Natural capital and ecosystem services informing decisions: from promise to practice. Proc. Natl. Acad. Sci. 112 (24), 7348-7355.

Hale, R., Turnbull, L., Earl, S., Childers, D., Grimm, N., 2015. Stormwater infrastructure controls runoff and dissolved material export from arid urban watersheds. Ecosystems 18 (1), 62-75.

Hammer, T.R., 1972. Stream channel enlargement due to urbanization. Water Resour. Res. 8 (6), 1530-1540.

Harney, K.R., 2011. Is Green Good for Resale Value?.

Hernández-Morcillo, M., Plieninger, T., Bieling, C., 2013. An empirical review of cultural ecosystem service indicators. Ecol. Indic. 29, 434-444.

Hopkins, L.D., Zapata, M.A., 2007. Engaging the Future: Forecasts, Scenarios, Plans, and Projects. Lincoln Institute for Land Policy, Cambridge, MA.

Horner, R.R., 1988. Biofiltration Systems for Storm Runoff Water Quality Control. Prepared for the Washington State Dept. of Ecology, Seattle, WA.

Houdeshel, C.D., Pomeroy, C.A., Hultine, K.R., 2012. Bioretention design for xeric climates based on ecological Principles1. JAWRA J. Am. Water Resour. Assoc. 48 (6), 1178-1190.

Hubacek, K., Kronenberg, J., 2013. Synthesizing different perspectives on the value of urban ecosystem services. Landsc. Urban Plan. 109 (1), 1-6.

Jacobs, M.H., Buijs, A.E., 2011. Understanding stakeholders' attitudes toward water management interventions: role of place meanings. Water Resour. Res. 47 (1).

Jantz, C.A., Manuel, J.J., 2013. Estimating impacts of population growth and land use policy on ecosystem services: a community-level case study in Virginia, USA. Ecosyst. Serv. 5 (0), 110-123.

Just, R.E., Hueth, D.L., Schmitz, A., 2004. The Welfare Economics of Public Policy: A Practical Approach to Project and Policy Evaluation. Edward Elgar Publishing, Cheltenham, UK.

Kaushal, S., Belt, K., 2012. The Urban watershed continuum: evolving spatial and temporal dimensions. Urban Ecosyst. 15, 409-435.

Kaźmierczak, A., 2013. The contribution of local parks to neighbourhood social ties. Landsc. Urban Plan. 109 (1), 31-44.

Keeley, M., Koburger, A., Dolowitz, D., Medearis, D., Nickel, D., Shuster, W.D., 2013. Perspectives on the use of green infrastructure for stormwater management in
Cleveland and Milwaukee. Environ. Manag. 51, 1093-1108.

Kiesecker, J.M., Copeland, H., Pocewicz, A., McKenney, B., 2010. Development by design: blending landscape-level panning with the mitigation hierarchy. Front. Ecol. Environ. 8 (5), 261-266.

Koryak, M., Hoskin, R.H., Reilly, R.J., Stafford, L.J., 2001. The impact of above grade sewerline crossings on the distribution and abundance of fishes in recovering small urban streams of the upper Ohio River Valley. J. Freshwater Ecol. 16 (4), 591-598.

Kousky, C., Olmstead, S.M., Walls, M.A., Macauley, M., 2013. Strategically placing Green infrastructure: cost-effective land conservation in the floodplain. Environ. Sci. Technol. 47 (8), 3563-3570.

La Rosa, D., Privitera, R., 2013. Characterization of non-urbanized areas for land-use planning of agricultural and green infrastructure in urban contexts. Landsc. Urban Plan. 109 (1), 94-106.

La Rosa, Daniele, Spyra, Marcin, Inostroza, Luis, 2016. Indicators of cultural ecosystem services for Urban planning: a review. Ecol. Indic. 61, 74-89.

Larson, E.K., Grimm, N.B., 2012. Small-scale and extensive hydrogeomorphic modification and water redistribution in a desert city and implications for regional nitrogen removal. Urban Ecosyst. 15 (1), 71-85.

Leopold, L.B., Huppman, R., Miller, A., 2005. Geomorphic effects of urbanization in fortyone years of observation. Proc. Am. Philos. Soc. 149 (3), 349-371.

Levin, L.A., Mehring, A.S., 2015. Optimization of bioretention systems through application of ecological theory. Wiley Interdiscip. Rev.: Water 2 (3), 259-270.

Lichfield, Nathaniel., 1960. Cost-benefit analysis in City planning. J. Am. Inst. Plann. 26 (4), 273-279.

Lovell, S., Taylor, J.R., 2013. Supplying urban ecosystem services through multifunctional green infrastructure in the United States. Landsc. Ecol. 28 (8), 1447-1463.

Luck, G.W., Chan, K.M.A., Klien, C.J., 2012. Identifying spatial priorities for protecting ecosystem services. F1000Research 1, 17.

Maestas, J.D., Knight, R.L., Gilgert, W.C., 2003. Biodiversity across a rural land-use gradient. Conserv. Biol. 17, 1425-1434.

Maringanti, C., Chaubey, I., Popp, J., 2009. Development of a multiobjective optimization tool for the selection and placement of best management practices for nonpoint source pollution control. Water Resour. Res. 45 (6).

Mascarenhas, A., Ramos, T.B., Nunes, L., 2012. Developing an integrated approach for the strategic monitoring of regional spatial plans. Land. Use Policy 29 (3), 641-651.

Mascarenhas, A., Ramos, T.B., Haase, D., Santos, R., 2014. Integration of ecosystem services in spatial planning: a survey on regional planners' views. Landsc. Ecol. 29 (8), 1287-1300.

McDonnell, M.J., Pickett, S.T.A., 1990. Ecosystem structure and function along Urbanrural gradients: an unexploited opportunity for ecology. Ecology 71 (4), 1232-1237.

McDonnell, M.J., Pickett, S.T.A., Groffman, P., Bohlen, P., Pouyat, R.V., Zipperer, W.C., Parmelee, R.W., Carreiro, M.M., Medley, K., 1997. Ecosystem processes along an Urban-to-rural gradient. Urban Ecosyst. 1, 21-36.

Medda, Francesca., 2012. Land value capture finance for transport accessibility: a review. J. Transp. Geogr. 25, 154-161.

Mendoza, G.A., Martins, H., 2006. Multi-criteria decision analysis in natural resource management: a critical review of methods and new modelling paradigms. For. Ecol. Manag. 230, 1-22.

Miles, B., Band, L.E., 2015. Green infrastructure stormwater management at the watershed scale: urban variable source area and watershed capacitance. Hydrol. Process. 29 (9), 2268-2274.

Millennium Ecosystem Assessment, 2005. Ecosystems and Human Wellbeing: Biodiversity Synthesis. World Resources Institute, Washington, D.C.

Mitsch, W.J., 2014. When will ecologists learn engineering and engineers learn ecology? Ecol. Eng. 65, 9-14.

Naiman, R.J., Décamps, H., 1997. The ecology of interfaces: riparian zones. Annu. Rev. Ecol. Syst. 621-658.

National Research Council, 2009. Urban Stormwater Management in the United States. The National Academies Press.

National Research Council, 2014. Sustainability Concepts in Decision-Making: Tools and Approaches for the US Environmental Protection Agency. National Academies Press, Washington, D.C.

Nelson, K., Palmer, M.A., 2007. Predicting stream temperature under urbanization and climate change: implications for stream biota. J. Am. Water Resour. Assoc. 43, $440-452$.

Netusil, N.R., Levin, Z., Shandas, V., Hart, T., 2014. Valuing Green infrastructure in Portland Oregon. Landsc. Urban Plan. 124, 14-21.

Norgaard, Richard B., 2010. Ecosystem services: from eye-opening metaphor to complexity blinder. Ecol. Econ. 69 (6), 1219-1227. http://dx.doi.org/10.1016/j. ecolecon.2009.11.009.

Nylen, N.G., Kiparsky, M., 2015. Accelerating Cost-Effective Green Stormwater Infrastrucure: Learning from Local Implementation. Berkeley Law Center for Law, Energy \& the Environment, Berkeley, CA.

Olander, Lydia, Maltby, Lorraine, 2014. Mainstreaming ecosystem services into decision making. Front. Ecol. Environ. 12 (10). http://dx.doi.org/10.1890/1540-9295-12.10 539. 539-539.

Opdam, P., 2013. Using ecosystem services in Community-based landscape planning: science is not ready to deliver. In: Fu, B., Jones, K.B. (Eds.), Landscape Ecology for Sustainable Environment and Culture. Springer, Dordrecht.

Palacios-Agundez, I., de Manuel, B.F., Rodríguez-Loinaz, G., Peña, L., Ametzaga-Arregi, I., Alday, J.G., Casado-Arzuaga, I., Madariaga, I., Arana, X., Onaindia, M., 2014. Integrating stakeholders' demands and scientific knowledge on ecosystem services in landscape planning. Landsc. Ecol. 29 (8), 1423-1433.

Patton, M.Q., 2001. Sage publications, thousand oaks, CA. Qualitative Research \& Evaluation Methods, 3rd edition. .

Paul, M.J., Meyer, J.L., 2001. Streams in the Urban landscape. Annu. Rev. Ecol. Syst. 32 
(1), 333-365.

Petter, M., Mooney, S., Maynard, S.M., Davidson, A., Cox, M., Horosak, I., 2012. A methodology to map ecosystem functions to support ecosystem services assessments. Ecol. Soc. 18 (1), 31.

Pickett, S., Buckley, G., Kaushal, S., Williams, Y., 2011. Social-ecological science in the humane metropolis. Urban Ecosyst. 14 (3), 319-339.

Plieninger, Tobias, Claudia, Bieling, Nora, Fagerholm, Anja, Byg, Tibor, Hartel, Hurley, Patrick, López-Santiago, C.ésar A., et al., 2015. The role of cultural ecosystem services in landscape management and planning. Curr. Opin. Environ. Sustain. 14, 28-33.

Portland BES, 2017. Combined Sewer Overflow Control. [Online]:. City of Portland Bureau of Environmental Services, Portland, OR. https://www.portlandoregon.gov/ bes/31030.

Ramaswami, A., Weible, C., Main, D., Heikkila, T., Siddiki, S., Duvall, A., Pattison, A., Bernard, M., 2012. A social-ecological-infrastructural systems framework for interdisciplinary study of sustainable City systems. J. Ind. Ecol. 16 (6), 801-813.

Reed, M.S., 2008. Stakeholder participation for environmental management: a literature review. Biol. Conserv. 141 (10), 2417-2431.

Revkin, A.C., 2008. Portland Again Tops Sustainability List. https://dotearth.blogs. nytimes.com/2008/09/22/portland-again-tops-a-sustainable-cities-list/.

Rohe, W.M., 2009. From local to global: one hundred years of neighborhood planning. J. Am. Plann. Assoc. 75 (2), 209-230.

Saha, D., Paterson, R.G., 2008. Local government efforts to promote the "Three Es" of sustainable development survey in medium to large cities in the United States. J. Plan. Educ. Res. 28 (1), 21-37.

Schaich, H., 2009. Local residents' perceptions of floodplain restoration measures in Luxembourg's Syr Valley. Landsc. Urban Plan. 93 (1), 20-30.

Scholes, R.J., Reyers, B., Biggs, R., Spierenburg, M.J., Duriappah, A., 2013. Multi-scale and cross-scale assessments of social-ecological systems and their ecosystem services. Curr. Opin. Environ. Sustain. 5 (1), 16-25.

Shandas, V., 2015. Neighborhood change and the role of environmental stewardship: a case study of green infrastructure for stormwater in the City of Portland, Oregon, USA. Ecol. Soc. 20 (3), 16.

Shandas, V., Messer, W.B., 2008. Fostering Green communities through civic engagement: lessons from 12 years of environmental stewardship in the Portland metropolitan area. J. Am. Plann. Assoc. 74 (4), 1-11.

Shandas, V., Steele, R., Nelson, A., 2012. Tabor to the River: An Evaluation of Outreach Efforts and Opportunities for Engaging Residents in Stormwater Management (Technical Report). Portland Bureau of Environmental Services, Portlan, OR.

Shipley, R., 2002. Visioning in planning: is the practice based on sound theory? Environ. Plann. A 34 (1), 7-22.

Shipley, R., Newkirk, R., 1998. Visioning: did anybody see where it came from? J. Plan. Literature 12 (4), 407-416.

Shmueli, D.F., Kaufman, S., Ozawa, C., 2008. Mining negotiation theory for planning insights. J. Plan. Educ. Res. 27 (3), 359-364.

Shuster, W.D., Bonta, J., Thurston, H., Warnemuende, E., Smith, D.R., 2005. Impacts of impervious surface on watershed hydrology: a review. Urban Water J. 2, 263-275.

Silvertown, J., 2015. Have ecosystem services been oversold? Trends Ecol. Evol. 30 (11), 641-648.

Sitas, N., Prozesky, H.E., Esler, K.J., Reyers, B., 2014. Opportunities and challenges for mainstreaming ecosystem services in development planning: perspectives from a landscape level. Landsc. Ecol. 29 (8), 1315-1331.

Slocombe, D.S., 1993. Environmental planning, ecosystem science, and ecosystem approaches for integrating environment and development. Environ. Manag. 17 (3), 289-303.

Steiner, F., 2014. Frontiers in urban ecological design and planning research. Landsc. Urban Plan. 125, 304-311.

Stone, B.J., Bullen, J.L., 2006. Urban form and watershed management: how zoning influences stormwater volumes. Environ. Plan. B 33, 21-37.

Sumarga, E., Hein, L., 2014. Mapping ecosystem services for land use planning, the case of Central Kalimantan. Environ. Manag. 54 (1), 84-97.

Susskind, L.E., Landry, E.M., 1991. Implementing a mutual gains approach to collective bargaining. Negot. J. 7 (1), 5-10.

Sustainlane, 2006. U.S. City Ranking.

TEEB, 2011. TTEEB Manual for Cities: Ecosystem Services in Urban Management. Econ. Ecosys. Biodiver. (TEEB) 48 Geneva Switzerland.

Trabucchi, M., Ntshotsho, P., O’Farrell, P., Comín, F.A., 2012. Ecosystem service trends in basin-scale restoration initiatives: a review. J. Environ. Manag. 111, 18-23.

Tzoulas, K., Korpela, K., Venn, S., Yli-Pelkonen, V., Kaźmierczak, A., Niemela, J., James, P., 2007. Promoting ecosystem and human health in urban areas using green infrastructure: a literature review. Landsc. Urban Plan. 81 (3), 167-178.

UK DEFRA, 2007. An Introductory Guide to Valuing Ecosystem Services. Department for Environment, Food and Rural Affairs, London.

UK NEA, 2012. UK National Ecosystem Assessment, Follow on Phase - Work Package 5: Cultural, Shared and Plural Values. UK National Ecosystem Assessment, London, UK. http://uknea.unep-wcmc.org/NEWFollowonPhase/ Whatdoesthefollowonphaseinclude/WorkPackage5/tabid/148/Default.aspx.

USEPA, 2013a. Final Ecosystem Goods and Services Classification System (FEGS-C) [EPA/ 600/R-13/ORD-004914]. US Environmental Protection Agency, Washington, D.C.

USEPA, 2013b. Water: Green Infrastructure. U.S. Environmental Protection Agency, Washington, D.C.

USFWS, 2015a. Environmental Conservation Online System. US Fish and Wildlife Service, Washington, D.C.

USFWS, 2015b. Information, Planning, and Conservation System. US Fish and Wildlife Service, Washington, D.C.

Vaissière, A.-C., Levrel, H., Hily, C., Le Guyader, D., 2013. Selecting ecological indicators to compare maintenance costs related to the compensation of damaged ecosystem services. Ecol. Indic. 29 (0), 255-269.

Viglizzo, E.F., Paruelo, J.M., Laterra, P., Jobbagy, E.G., 2012. Ecosystem service evaluation to support land-use policy. Agric. Ecosyst. Environ. 154, 78-84.

Walsh, C.J., Allison, H.R., Feminella, J.W., Cottingham, P.D., Groffman, P.M., Morgan, R.P., 2005. The urban stream syndrome: current knowledge and the search for a cure. J. N. Am. Benthol. Soc. 24, 706-723.

WEF/ASCE (Ed.), 2012. Design of Urban Stormwater Controls. Water Environment Federation, American Society of Civil Engineers/Environmental Water Resources Institute, Alexandria and Reston, Virginia.

Wilbur, Sandra, Fowler, Mike, Pratt, Robert, 2017. Durham, NC: City of Durham Public Works Department. South Ellerbe Stormwater Restoration Project Design Workshop [Online]: http://durhamnc.gov/DocumentCenter/View/16915.

Wilkinson, C., Saarne, T., Peterson, G.D., Colding, J., 2013. Strategic spatial planning and the ecosystem services concept-an historical exploration. Ecol. Soc. 18 (1), 37.

Wilson, M.A., Howarth, R.B., 2002. Discourse-based valuation of ecosystem services: establishing fair outcomes through group deliberation. Ecol. Econ. 41 (3), 431-443.

Winemiller, K.O., Flecker, A.S., Hoeinghaus, D.J., 2010. Patch dynamics and environmental heterogeneity in lotic ecosystems. J. N. Am. Benthol. Soc. 29 (1), 84-99.

Wise, Steve., 2008. Green infrastructure rising. Planning 74 (8), 14-19.

Woods-Ballard, B., Kellagher, R., Martin, P., Jefferies, C., Bray, R., Shaffer, P., 2007. The SUDS Manual. CIRIA Report C697. Construction Industry Research and Information Association, London, UK.

Yeakley, J.A., Bollens, S., Duncan, S., Ozawa, C., Shandas, V., 2011. The PortlandVancouver ULTRA-Ex project: examining the role of governance in urban environmental management. In: 97th Annual Meeting of the Ecological Society of America Annual Meeting. Austin, Texas.

Young, R.F., McPherson, E.G., 2013. Governing metropolitan green infrastructure in the United States. Landsc. Urban Plan. 109 (1), 67-75.

Zhu, W.-X., Dillard, N., Grimm, N., 2004. Urban nitrogen biogeochemistry: status and processes in green retention basins. Biogeochemistry 71 (2), 177-196.

Zimmerman, R., 2009. Making infrastructure competitive in an Urban world. Ann. Am. Acad. Polit. Soc. Sci. 626 (1), 226-241. 